\title{
Periodic and episodic benthos recruitment in southwest Mecklenburg Bay (western Baltic Sea)
}

\author{
J. Prena ${ }^{1}$, F. Gosselck ${ }^{2}$, V. Schroeren ${ }^{3} \& J$. Voss $^{3}$ \\ 'Institut für Ostseeforschung Warnemünde; Pf. 30 10 38, D-18111 Rostock, Germany* \\ ${ }^{2}$ Institut für Angewandte Ökologie GmbH; Lindenweg 2, D-18184 Neu \\ Broderstorf, Germany \\ ${ }^{3}$ Landesamt für Wasserhaushalt und Küsten Schleswig-Holstein; Saarbrückenstr. 38, \\ D-24114 Kiel, Germany
}

\begin{abstract}
Temporal changes in the zoobenthos of southwest Mecklenburg Bay were studied using routine survey data collected in 1980-94. Earlier studies suggested that long-term oxygen deficiency on the scale of several months affects the zones below $20 \mathrm{~m}$ depth. Episodic benthic recolonization occurred during periods with improved oxygen conditions, as a rule by opportunistic polychaetes followed by some actively immigrating adult species. However, these observations were restricted to central and southern Lübeck Bay. Our recent data indicate that benthic recolonization exhibits greater regularity along the northern shore of Lübeck Bay. Special wind conditions and water exchange processes in the western Baltic Sea are likely to displace the deep water in northern Lübeck Bay more rapidly than in the southern zones. By means of multidimensional scaling, two types of episodic recruitment are identified in the benthos that are probably related to enhanced nitrogen discharge through river runoff in the winter and exceptionally weak water stratification in the summer.
\end{abstract}

\section{INTRODUCTION}

The environmental status of Lübeck Bay, an approximately $400 \mathrm{~km}^{2}$ large embayment situated in southwest Mecklenburg Bay, has been studied intensively since the 1980s. Large populations of the opportunistic polychaetes Capitella capitata and Polydora ciliata occurred in some deeper zones in June 1980, where surveys carried out in the late 1970s failed to demonstrate any benthos (Gosselck \& Georgi, 1984). This recolonization event stimulated further studies, creating the basis for the later National Coastal Benthos Monitoring Program. Early results suggested that the zones of Lübeck Bay below $20 \mathrm{~m}$ depth belonged to the Belt Sea regions most severely affected by lack of oxygen (Gosselck et al., 1987). Although sampling programs were, as a rule, restricted to the central and southern parts (Hagmeier, 1930; Schulz, 1969; Gosselck \& Georgi, 1984), the environmental status of Lübeck Bay was occasionally generalized for all its deeper zones (Ehrhard \& Wenck, 1984; Gosselck, 1992). More information about the benthos distribution in Mecklenburg Bay is now provided by the Landesamt für Wasserhaushalt und Küsten, Schleswig-Holstein (LW). This paper presents and discusses the data covering the spatial and

\footnotetext{
- Send requests for reprints to Ute Fensky at the above address in Rostock
} 
temporal distribution of zoobenthos which has been collected in southwest Mecklenbury Bay since 1980. Emphasis is placed on the overall variability of the benthic community. forming necessary background information for future environmental assessments.

\section{MATERIAL AND METHODS}

Data obtained by routine benthos surveys carried out at Rostock University (Stations LB7 and LB12, 1980-91) and the LW Schleswig-Holstein (Stations MB4-8 and MB10. 1987-94) were used in this study (Table 1, Fig. 1). Three replicate grab samples of $0.1 \mathrm{~m}^{2}$ each were taken and washed through a $1-\mathrm{mm}$ screen. Biomass was determined as dsh free dry weight (ignition at $520^{\circ} \mathrm{C}$ ) after preservation in $4 \%$ buffered formaldehyde-seawater. The biomass of Stations LB7 and LB12 was estimated from wet weight data using

Table 1. Position and depth of the monitoring stations in Mecklenburg Bay employed in this study

\begin{tabular}{|cccc|}
\hline Station & Longitude & Latitude & Depth [m] \\
\hline LB7 & $11^{\circ} 12.3^{\prime}$ & $54^{\circ} 00.7^{\prime}$ & $23-24$ \\
LB12 & $11^{\circ} 27.8^{\prime}$ & $54^{\circ} 10.4^{\prime}$ & $22-23$ \\
MB4 & $11^{\circ} 13.3^{\prime}$ & $54^{\circ} 122^{\prime}$ & 19 \\
MB5 & $11^{\circ} 04.1^{\prime}$ & $54^{\circ} 06.9^{\prime}$ & 21 \\
MB6 & $10^{\circ} 54.5^{\circ}$ & $54^{\circ} 02.5^{\prime}$ & 21 \\
MB7 & $10^{\circ} 563^{\prime}$ & $54^{\circ} 00.3^{\prime}$ & 19 \\
MB8 & $10^{\circ} 47.5^{\prime}$ & $54^{\circ} 02.0^{\prime}$ & 16 \\
MB10 & $11^{\circ} 15.6^{\prime}$ & $54^{\circ} 22.0^{\prime}$ & 16 \\
O1 & $11^{\circ} 02.7^{\prime}$ & $54^{\circ} 03.5^{\prime}$ & 24 \\
O2 & $11^{\circ} 12.5^{\circ}$ & $54^{\circ} 05.4^{\prime}$ & 24 \\
O3 & $11^{\circ} 25.0^{\prime}$ & $54^{\circ} 07.9^{\prime}$ & 23 \\
O4 & $11^{\circ} 41.7^{\prime}$ & $54^{\circ} 12.1^{\prime}$ & 25 \\
\hline
\end{tabular}

unpublished conversion factors established for the study area. Oceanographic data of Stations O1-O4 (Fig. 1) were kindly supplied by the Landesamt für Umwelt und Natur Mecklenburg-Vorpommern, runoff data of Trave river at Sehmsdorf by the LW Schleswig-Holstein. Dr. T. Schmidt (Warnemünde) processed the wind data of Boltenhagen weather station provided by the Deutscher Wetterdienst Offenbach. Interannual differences in the water stratification were studied using the density gradient $\nu_{0}$ measured between water surface and sea floor. The area below the graph $f(\lambda \sigma$, time) describes the mean vertical density gradient of a year and was used to compare the degree of water stratification between years.

Multidimensional Scaling (MDS) and Principal Component Analysis (PCA) were used to explore the temporal changes in the benthic community. PCA yields uncorrelated variables which are ordered in terms of decreasing fractions of the total variance of the original variables. MDS seeks to arrange objects in a given number of dimensions, so that objects of greater similarity group closer to each other than those with less. Euclidean distance of $\log (x+1)$-transformed abundance data was used in MDS. PCA of Station M4 used the correlation matrix of $\log (x+1)$-transformed abundance data. The methods are described in most statistical textbooks, and have increasingly been used in benthos studies (e.g. Olsgard \& Gray, 1995). 


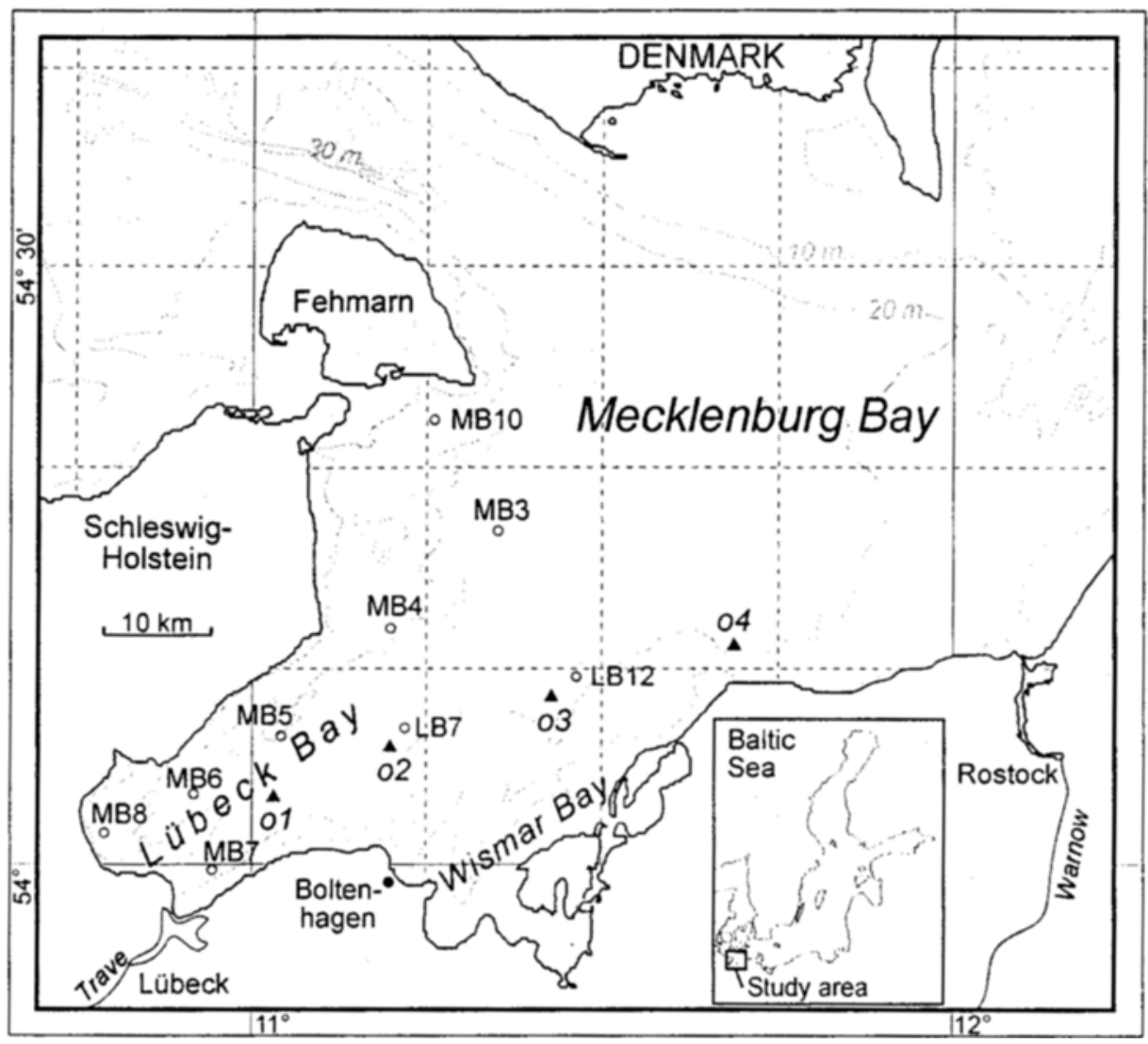

Fig. 1. Map of Mecklenburg Bay showing the bottom profile and the location of sampling sites

\section{RESULTS}

\section{Benthos}

A total of 96 species were identified in the 176 samples taken at Stations LB7, LB12 and MB4-MB8. Polychaetes ranked first with 45 species, followed by the molluscs (23), crustaceans (17), cnidaria (4), priapulid worms (2), echinoderms (2), nemerteans (1), oligochaetes (1) and tunicates (1). A considerable temporal variation was observed in the number of species present at each station. As a rule, there was an increase or little change from spring to summer, and a decline toward the autumn (Figs 2 and 3 ). This was most evident at the stations deeper than $20 \mathrm{~m}$, such as Stations MB5, MB6, LB7 and LB12. Little or no decline occurred in the shallower and outer zones, particularly at Station MB4. This pattern varied considerably from year to year. The number of species present at the deeper stations was constantly low in 1989. Station LB12 being an exception (Figs 2 and 3). Only a few species colonized at Station LB7 in 1986 and 1987. In contrast, 


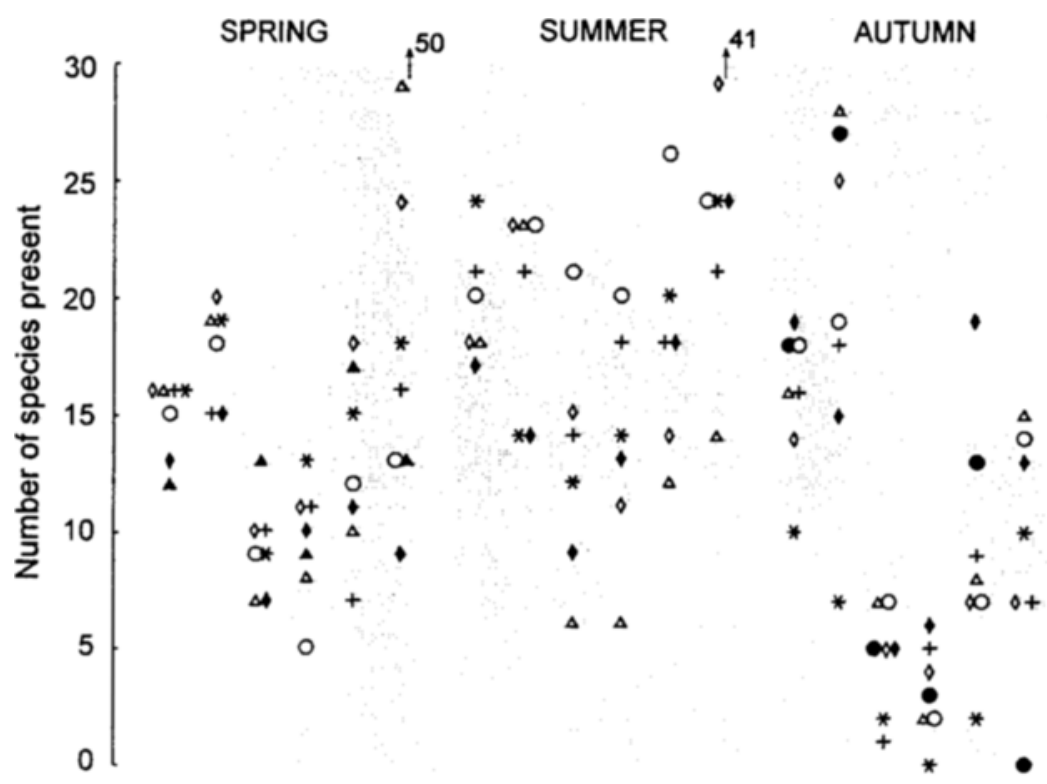

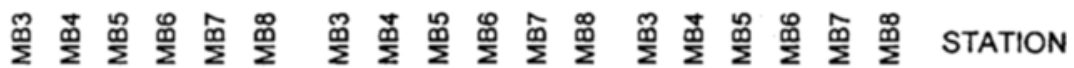

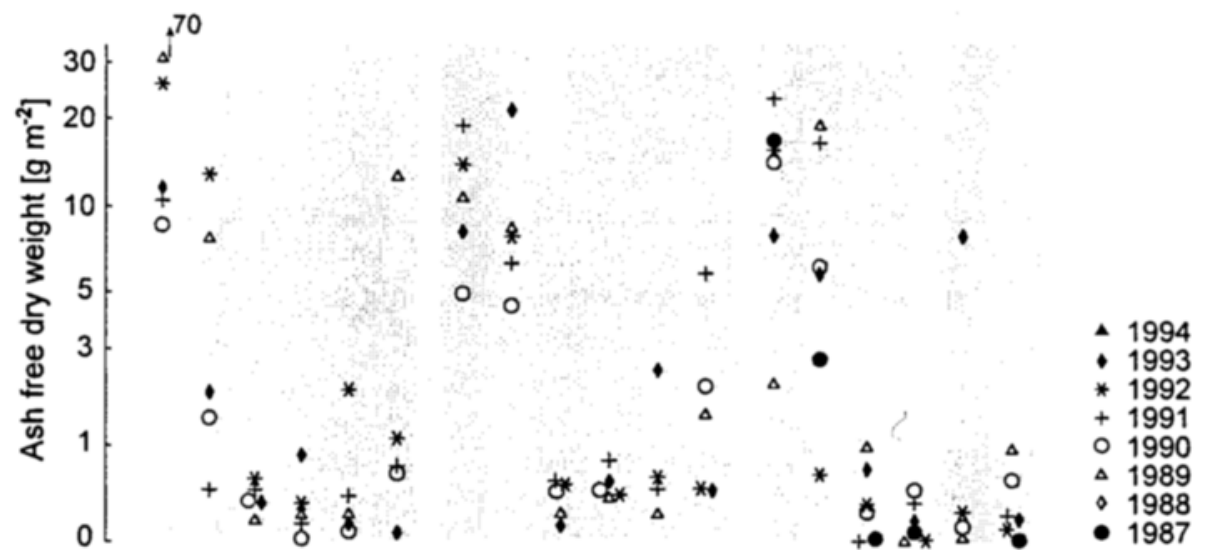

Fig. 2. Biomass and number of species present at Stations MB3-MB8 in 1987-94. Note non-linear scale in biomass

the benthos was comparatively diverse in 1990. At the shallow Station MB8, a comparatively large number of species occurred in the summer 1988 and in the spring 1989.

Total biomass was highest at Stations MB3, MB4 and LB12, and, as a rule, below $2 \mathrm{~g}$ ash free dry weight $\mathrm{m}^{-2}$ at the stations in inner Lübeck Bay (Figs 2 and 3). Biomass at Station MB8, even though this station was only $16 \mathrm{~m}$ deep, was similarly low. Large interannual variation in the biomass data occurred at Station LB12, with values $>5 \mathrm{~g} \mathrm{~m}^{-2}$ in 1980, 1981, 1986, and 1988-91 (Fig. 3). 

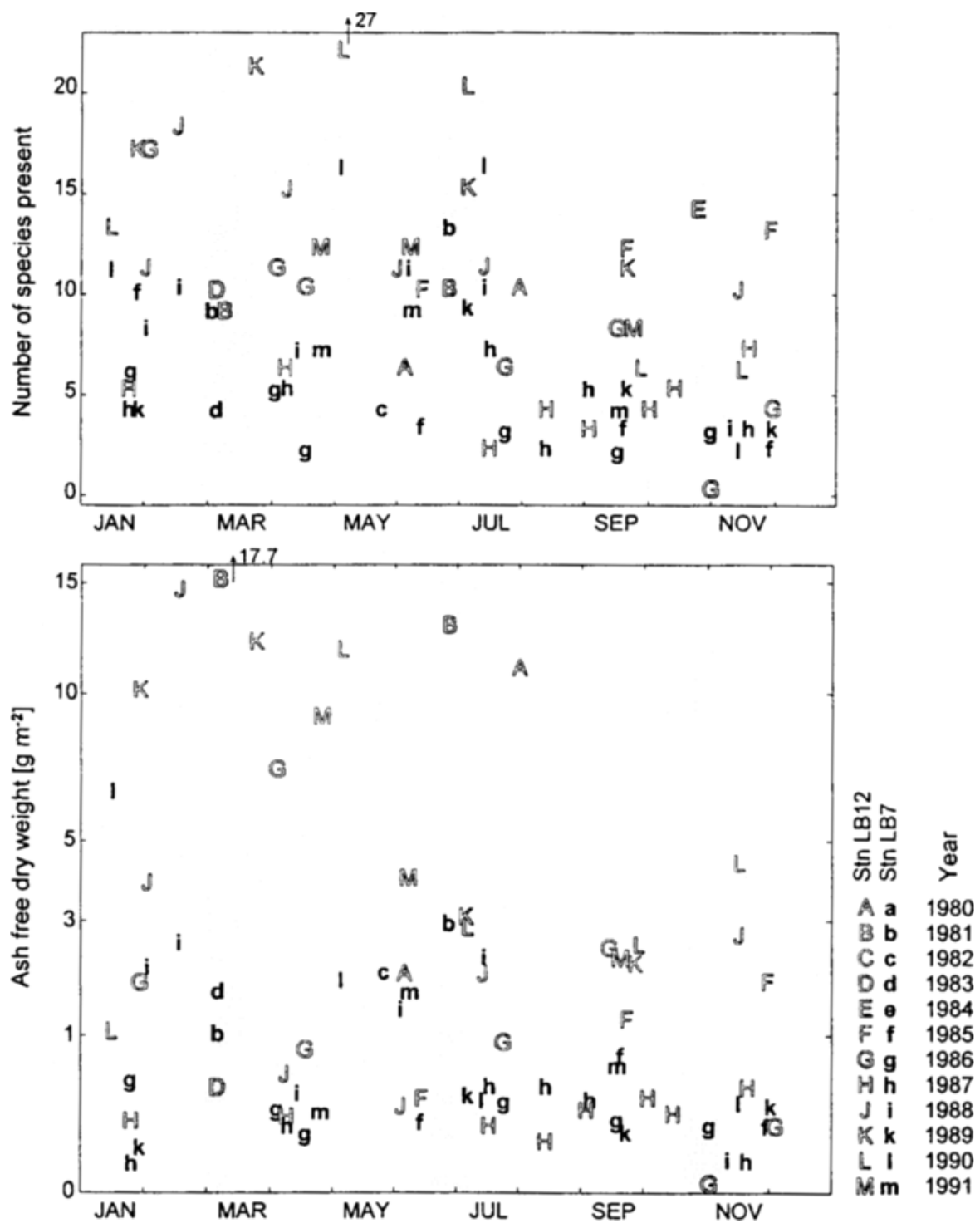

Fig. 3. Biomass and number of species present at Stations LB7 and LB12 in 1980-91. Note non-linear scale in biomass. Areas shaded illustrate the sampling time shown in Figure 2

Stations LB7 and LB12 showed some episodes of greater faunal change, but re-established their former benthic community (Fig. 4). The temporal occurrence of these alternations was essentially in agreement at both stations, with episodes of stronger colonization in 1980-84,1985,1988, and 1990. The abundance of species found in these time periods was compared with that of average observations, encircled in the MDS-diagrams, in Tables 2 (Station LB7) and 3 (Station LB12). In 19 observations, the polychaete species 
Capitella capitata, Polydora ciliata and Bylgides sarsi, and the priapulid Halicryptus spinulosus typically formed a benthic community of low diversity at Station LB7, with an average of 77 individuals $\mathrm{m}^{-2}$ and $<4$ species present (Table 2). There were strong increases in the numbers of $C$. capitata and $P$. ciliata in the four time periods identified by MDS (Fig. 4A), often accompanied by an increase in the number of species present. Halicryptus spinulosus, B. sarsi, Scoloplos armiger and Diastylis rathkei colonized in large numbers in 1981, particularly in June. The benthos was diverse in the summer of 1990 , when species such as Arctica islandica, Corbula gibba, Mya arenaria, Mytilus edulis, Syndosmya alba, Nephtys sp. and Nereimyra punctata colonized. Capitella capitata was absent in this time period. The 1990 colonization at Station LB7 showed differences from the other colonization episodes (Fig. 4A). The benthos at Station LB12 was more diverse compared to that at Station LB7, with a mean of 201 individuals $\mathrm{m}^{-2}$ and nine species present in 29 observations without previous recolonization (Table 3). Abundant species with regular occurrence were $H$. spinulosus, Priapulus caudatus, B. sarsi, C. capitata, Heteromastus filiformis, P. ciliata, A. islandica, C. gibba and D. rathkei. In 1980-85 species such as $C$. capitata, $D$. rathkei, $P$. ciliata and $S$. alba occurred occasionally in large numbers (Table 3). Capitella capitata was abundant in February 1988 and again in November 1988 , with $>1000$ individuals $\mathrm{m}^{-2}$. The 1990 colonization episode started with $P$. ciliata followed by a general increase in the number of species present. Several molluscs colonized, such as Astarte borealis, A. elliptica, Cerastoderma lamarcki, Corbula gibba, Mysella bidentata, Mytilus edulis and S. alba (Table 3). Capitella capitata was, as a rule, absent in this time period. The MDS diagram illustrates that the 1990 colonization was different from earlier recruitments (Fig. 4B).

The benthos at Station MB4 changed from year to year and between seasons (Fig. 5). Samples taken in the spring showed, as a rule, less loading in the second principal axis (i.e. they are shifted downward in the diagram) when compared to the samples taken in the autumn or summer (Fig. 5). This can partly be explained by increased occurrence of $C$. capitata in the spring. The PCA diagram further suggests that the abundance of species such as $S$. alba, C. gibba, M. bidentata and Nephtys hombergii had increased in the early 1990s. Figure 6A illustrates that these species occurred infrequently before the autumn 1989, but were more common in 1990-92. Corbula gibba was abundant still in 1993. Mysella bidentata, C. gibba and S. alba occurred more frequently at the shallow Station MB10, south of Fehmarn Island. Their populations increased in the autumn 1989 (Fig. 6B). Changes similar to those described for Station MB4 were also apparent at Station MB3, but are not illustrated here.

Seasonal changes were evident in the benthic community at Stations MB5 and MB6 (Fig. 7). The benthos was, as a rule, more diverse in summer and collapsed in autumn. Polydora ciliata and C. capitata were predominant at Station MB6 throughout the year but occurred in lower numbers in the autumn. Predators such as $P$. caudatus, B. sarsi, Anaitides mucosa and Eteone longa colonized only in the spring and summer, and were absent in the autumn. Greater numbers of $D$. rathkei showed up only in the summer. Notable deviations from this colonization pattern occurred in the summers 1988-90. Capitella capitata colonized with 1100-1700 specimens $\mathrm{m}^{-2}$ in 1988 . The benthos was less diverse throughout 1989 (till spring 1990), and similar to the impoverished benthos collected in the autumn of other years. The 1990 colonization was particularly strong, with 
Benthos recruitment in southwest Mecklenburg Bay

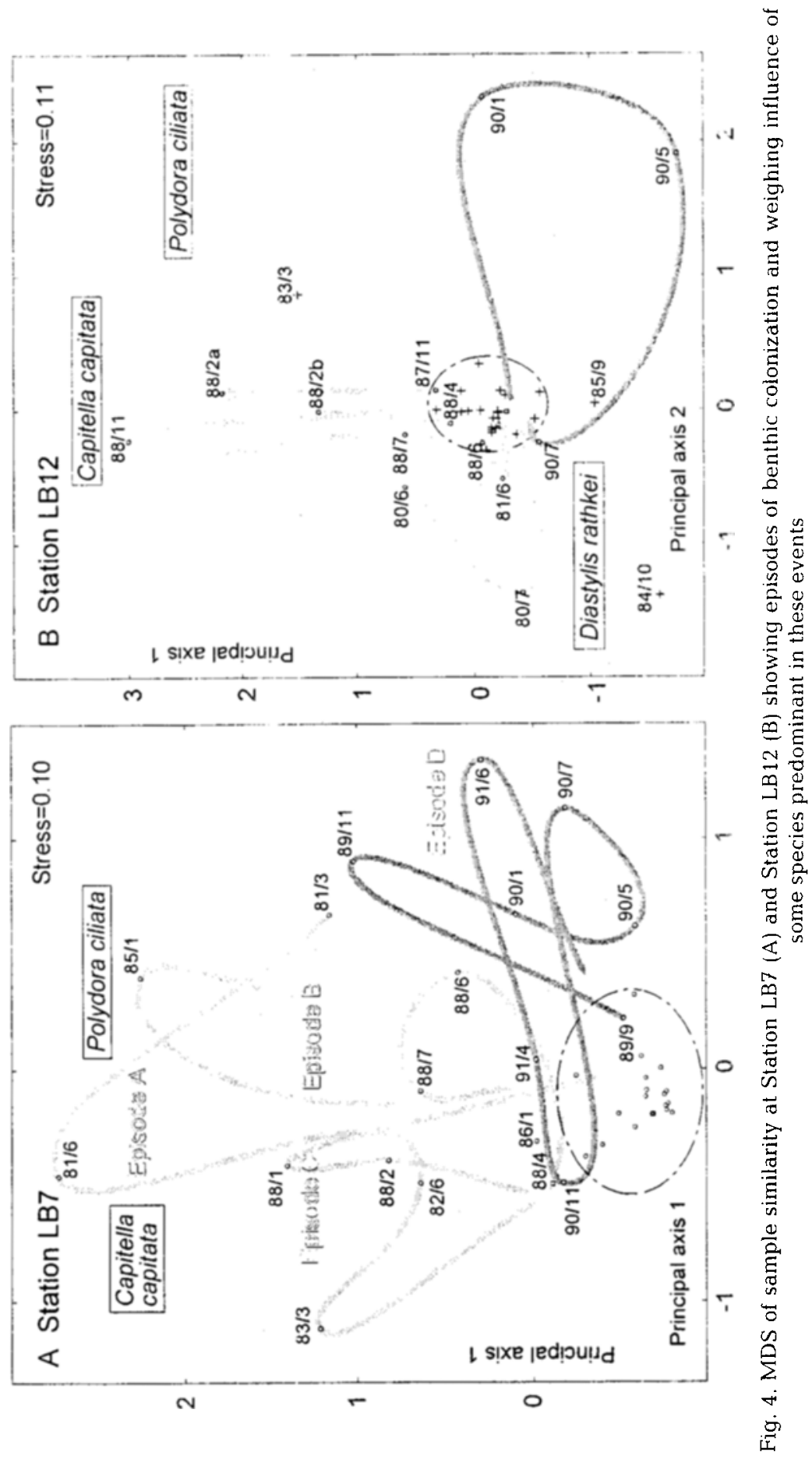




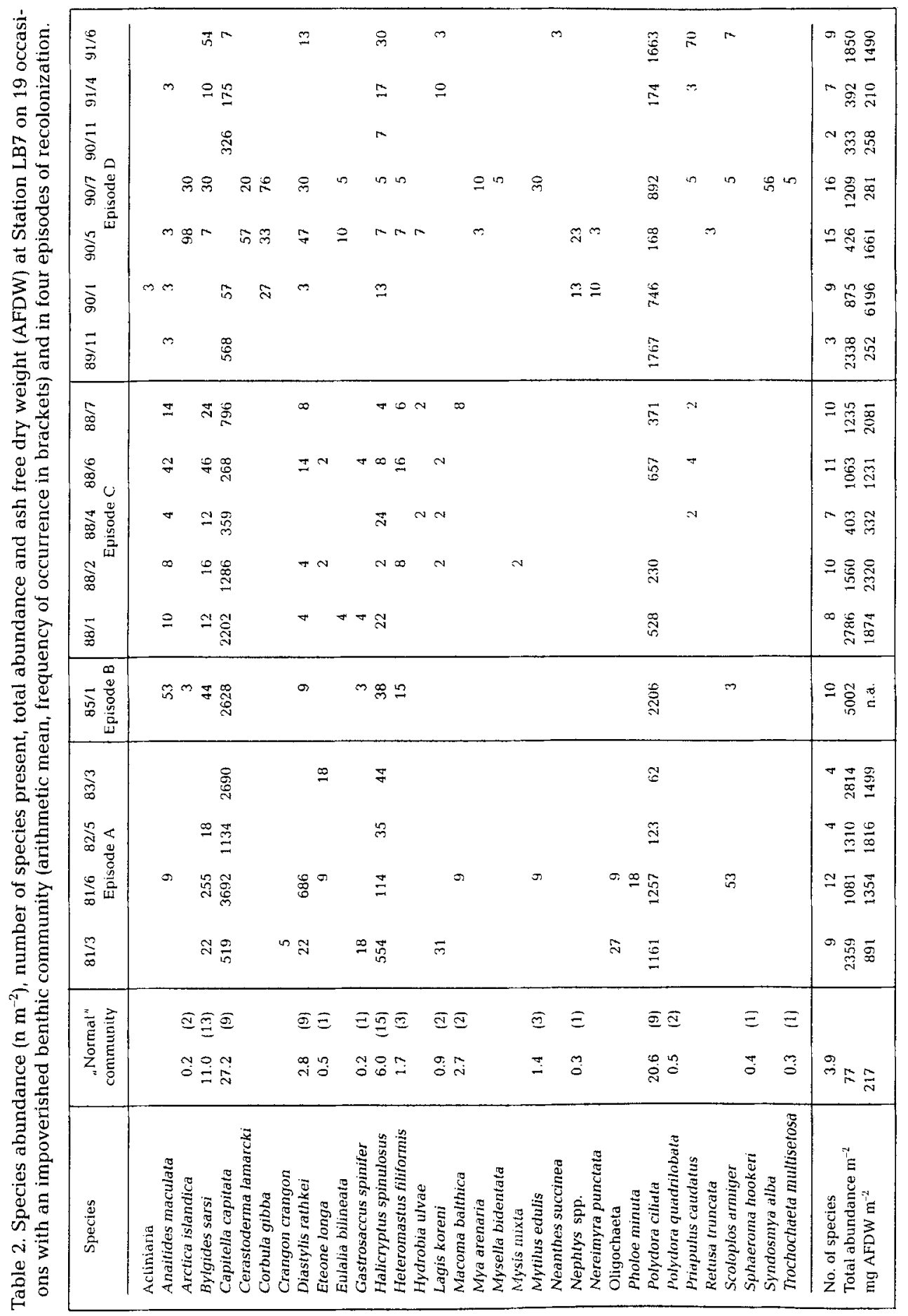




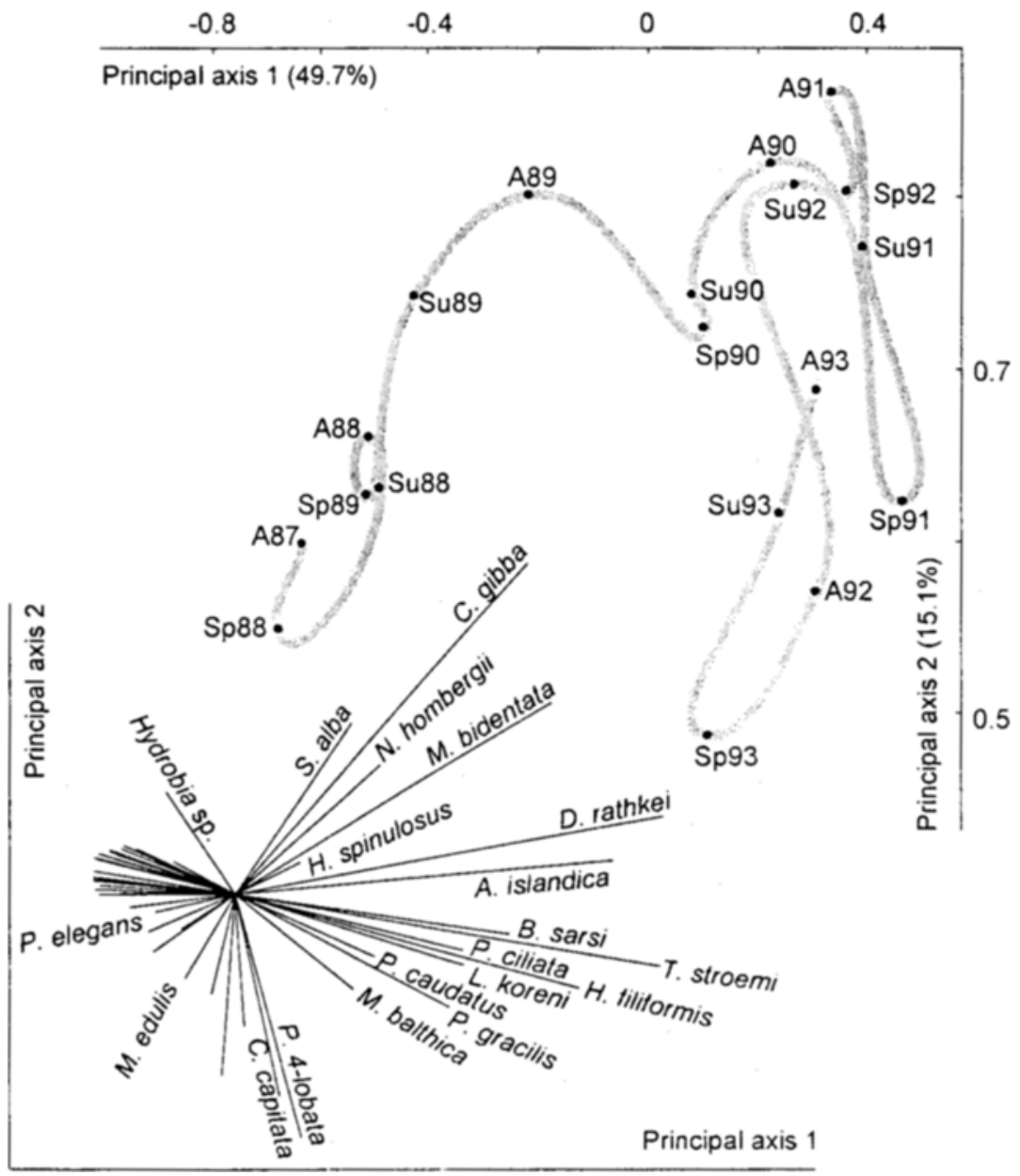

Fig. 5. PCA of the benthic community at Station MB4 in 1987-94 demonstrating an increase of some species in the early 1990s (Sp - spring, Su-summer, A - autumn)

several molluscs such as A. islandica, C. gibba, Macoma balthica, S. alba and Mya truncata being present. Similar seasonal changes were apparent at Station MB5. Capitella capitata was abundant only in the springs 1988, 1989, 1991 and 1992, and in the summer $1988\left(1100 \mathrm{~m}^{-2}\right)$.

Episodes of major benthic colonization were apparent at Station MB8 between 1988 and 1991 (Fig. 8). Mytilus edulis and Pygospio elegans were very abundant in the summer 1988. However, these populations had vanished by autumn, while C. capitata and $P$. ciliata occurred in large numbers. Molluscs such as C. gibba, M. bidentata and S. alba colonized in the spring 1989, and the benthos exhibited remarkable diversity (Fig. 2). Some colonization occurred in the summers 1990, 1991 and 1993, whereas recruitment was poor in 1989 and 1992 (Figs 2 and 8). Mytilus edulis, P. elegans and P. ciliata domi- 


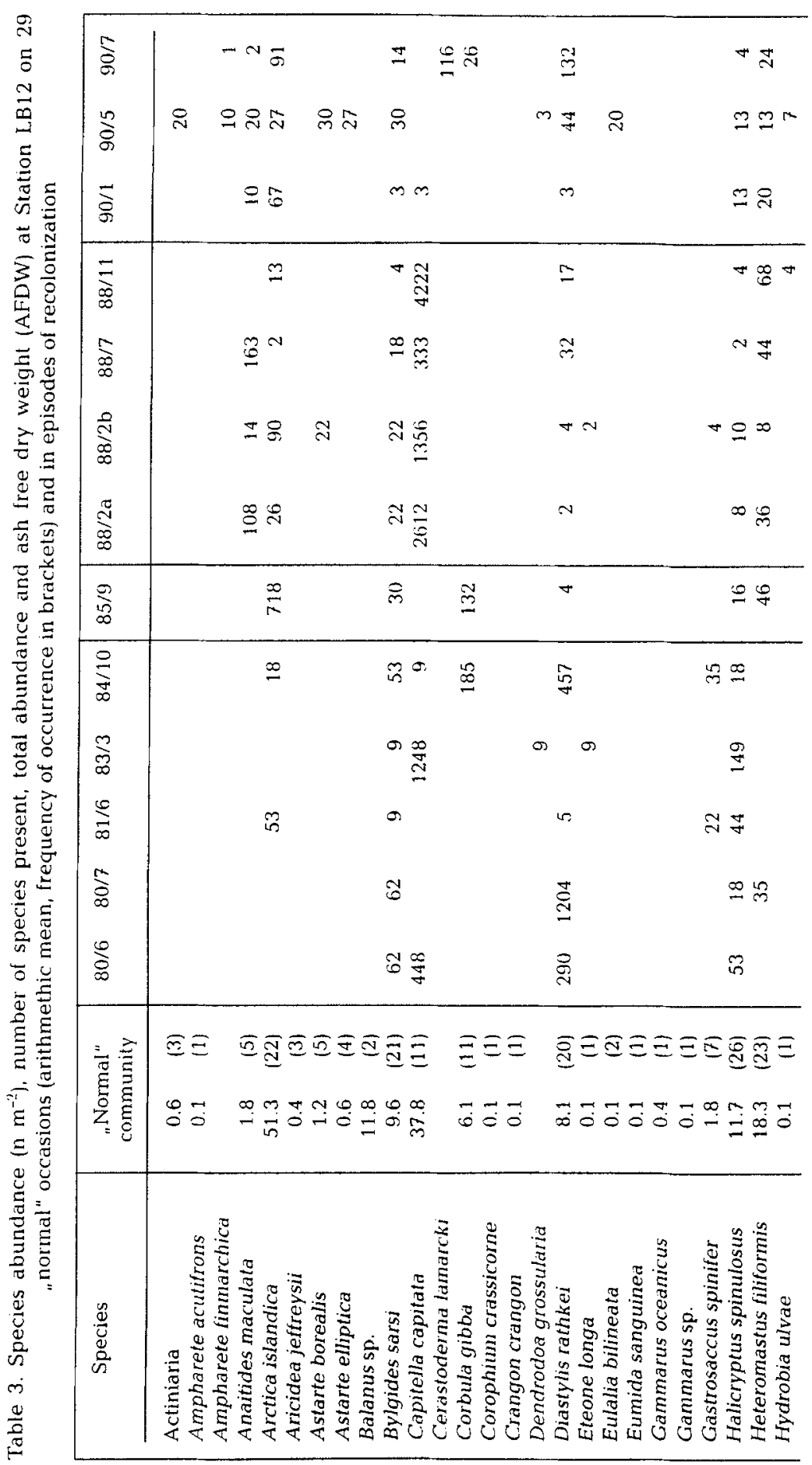


Benthos recruitment in southwest Mecklenburg Bay






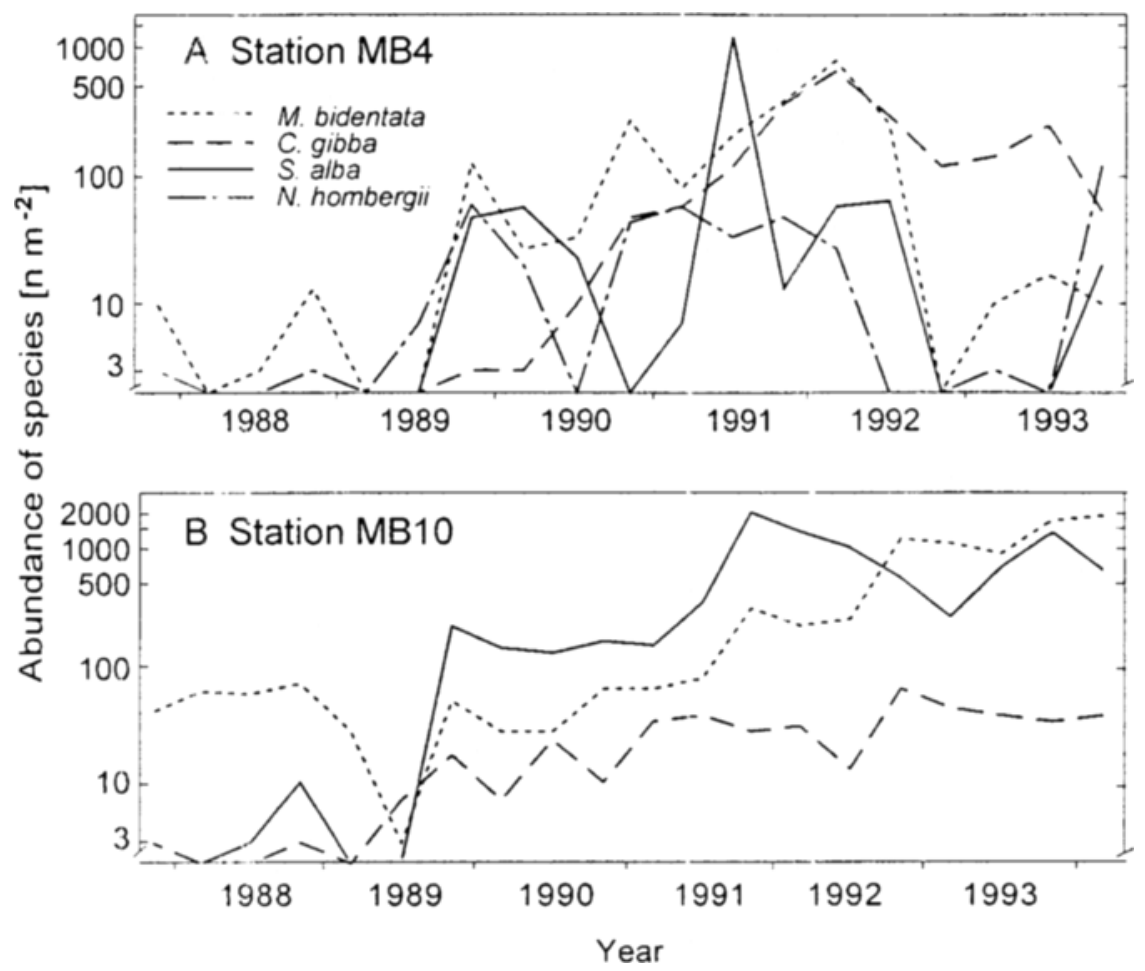

Fig. 6. Abundance (n $\mathrm{m}^{-2}$ ) of $S$. alba, C. gibba, M. bidentata and N. hombergii at Station MB4 (A) and Station MB10 (B) in 1987-93. Note non-linear scale

nated in 1993. Macoma balthica and Hydrobia sp. were the dominants in 1990 and 1991. Samples of a particular season were less similar to one another than at Stations MB5 and MB6.

\section{Oceanographic and weather conditions}

Oxygen conditions near the bottom deteriorated in Lübeck Bay between April and September when a pycnocline was established. The density of the deep water was on average greater in inner Lübeck Bay than in Mecklenburg Bay (Fig. 9A). A similar gradient occurred in oxygen saturation near the sea floor in the summer, with the lowest average oxygen saturation found at Station $O 1$ in September (Fig. 9B).

Interannual differences in the stratification of water masses were studied at Stations O1-O4 using the mean annual density gradient between the top and bottom water layers. A strongly marked stratification occurred in 1981 and 1988, and to a lesser degree in 1976, 1985 and 1987. Stratification was weak in 1980, 1989-90 and 1992-93 (Fig. 10). Westerly winds of $3-10 \mathrm{~m} \mathrm{~s}^{-1}$ prevailed during the period of strongest stratification, July-September, at Boltenhagen weather station (Fig. 11). Winds from the east occurred too, but were less common. Conditions were very stable in July/August 1988, with weak 


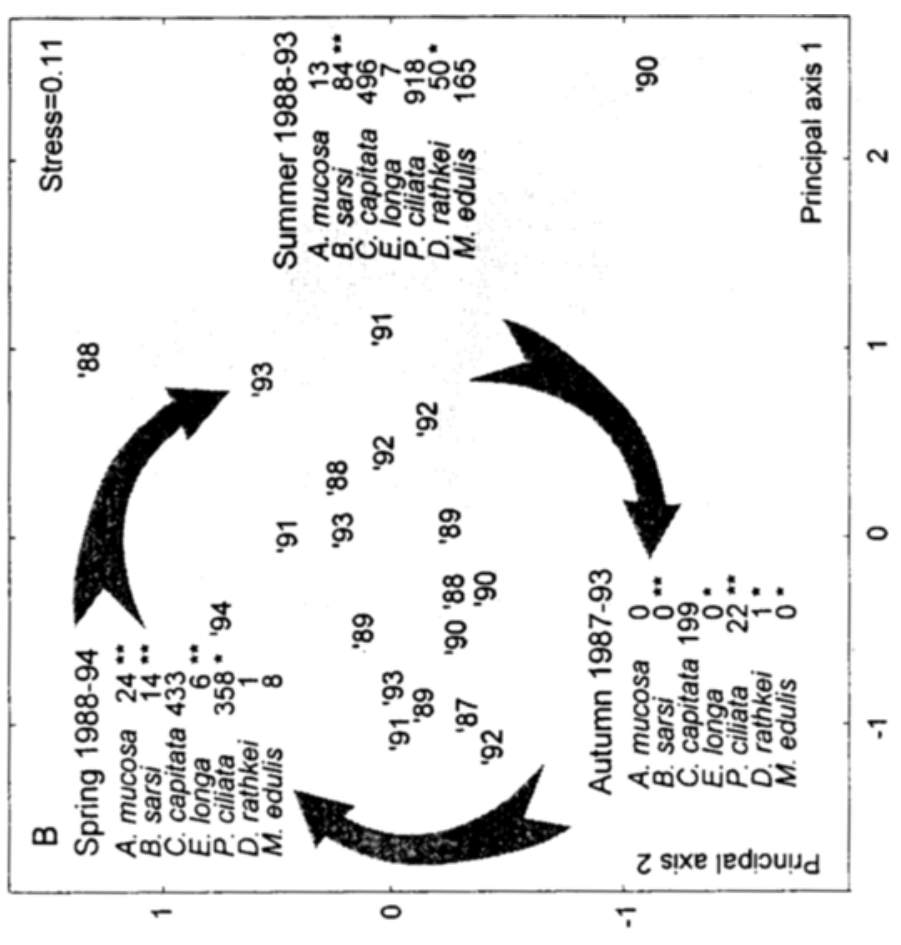

둥

를

它

突

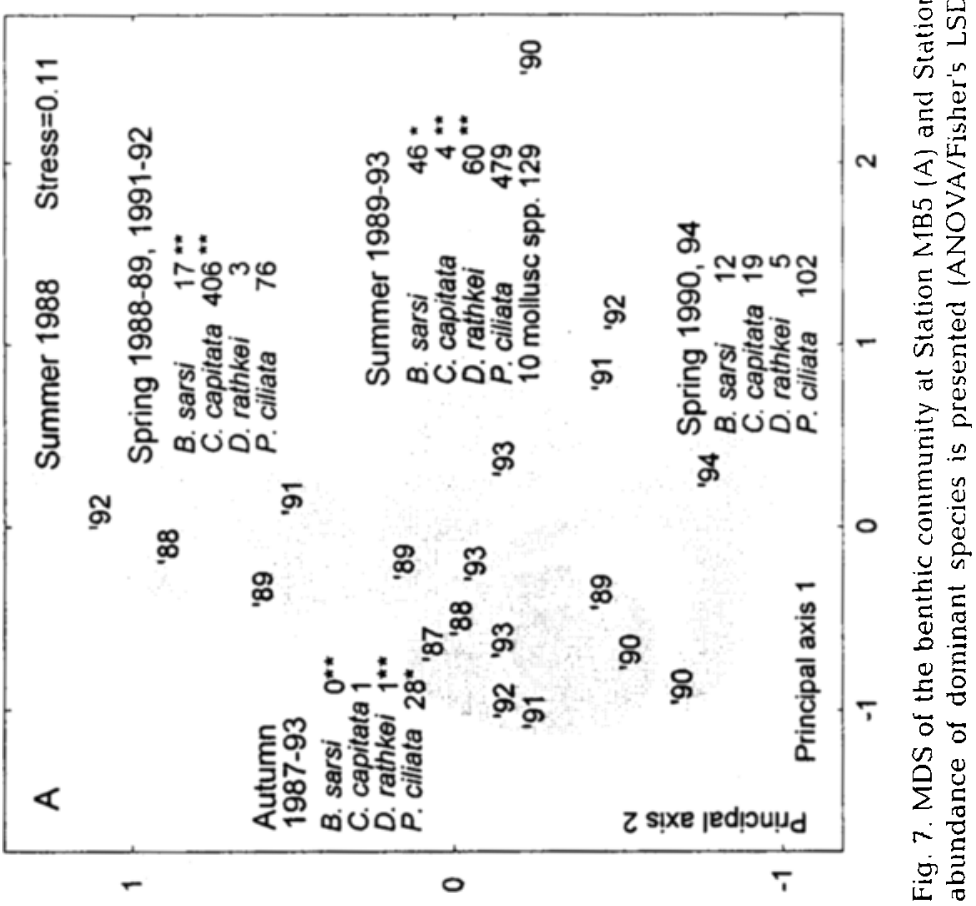




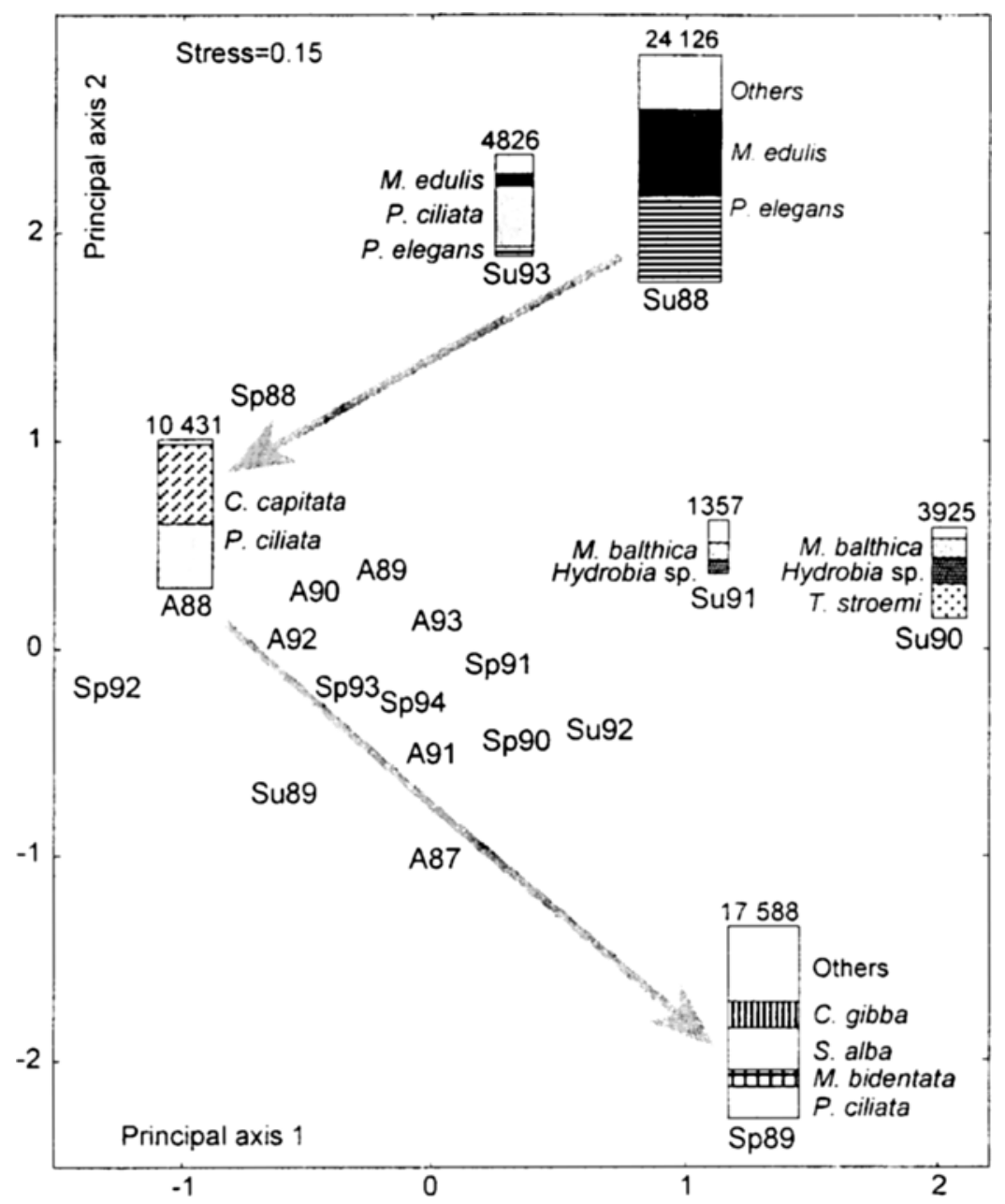

Fig. 8. MDS of the benthic community at Station MB8 in 1987-94 showing total abundance and dominant species in some episodes of rapid colonization (Sp - spring, Su - summer, A - autumn)

west winds of $2-5 \mathrm{~m} \mathrm{~s}^{-1}$ on average and slight east winds (Fig. 12). There was a higher proportion of prevailing east winds in the other years, both in years with high and low water stratification (Fig. 12).

The greatest source of freshwater runoff to Lübeck Bay is the river Trave, draining $726 \mathrm{~km}^{2}$ of mainly agricultural land. Maximum runoff occurred as a rule between January and March, and was low in the summer. Figure 13 shows the monthly runoff in 1981-94, averaged for January-March, May-October and January-December of each year. Runoff in January-March was high in the years 1981, 1988 and 1994, but was below average in 1989-93. There was little difference between the summer runoffs, 1987 being an exception. The yearly runoff was greatly determined by that of 

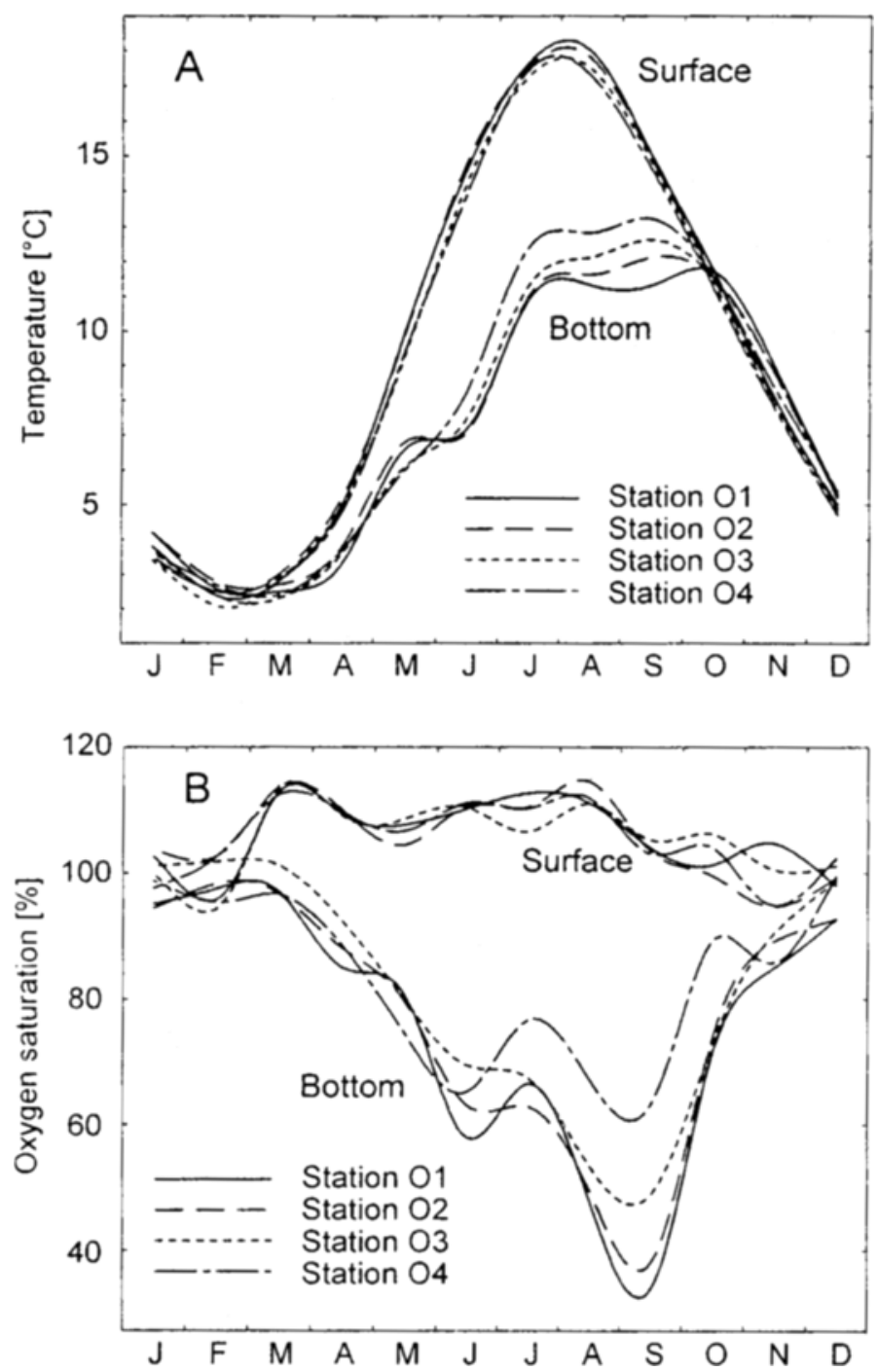

Fig. 9. Monthly means of temperature (A) and oxygen saturation (B) in the surface and bottom water at Stations O1-O4 in 1975-93

the January-March period, although the yearly means varied less between years (Fig. 13).

A regression was calculated between freshwater runoff in the winter period (November-March) and total nitrogen and the sum of nitrite and nitrate, respectively. Nitrogen concentration increased significantly for volume flows up to $6 \mathrm{~m}^{3} \mathrm{~s}^{-1}$. No further increase was apparent when current velocity was $6-30 \mathrm{~m}^{3} \mathrm{~s}^{-1}$. In other words, very high river runoff caused an increase in the nitrogen load through greater volume flows, while the nitrogen concentration remained generally constant. 


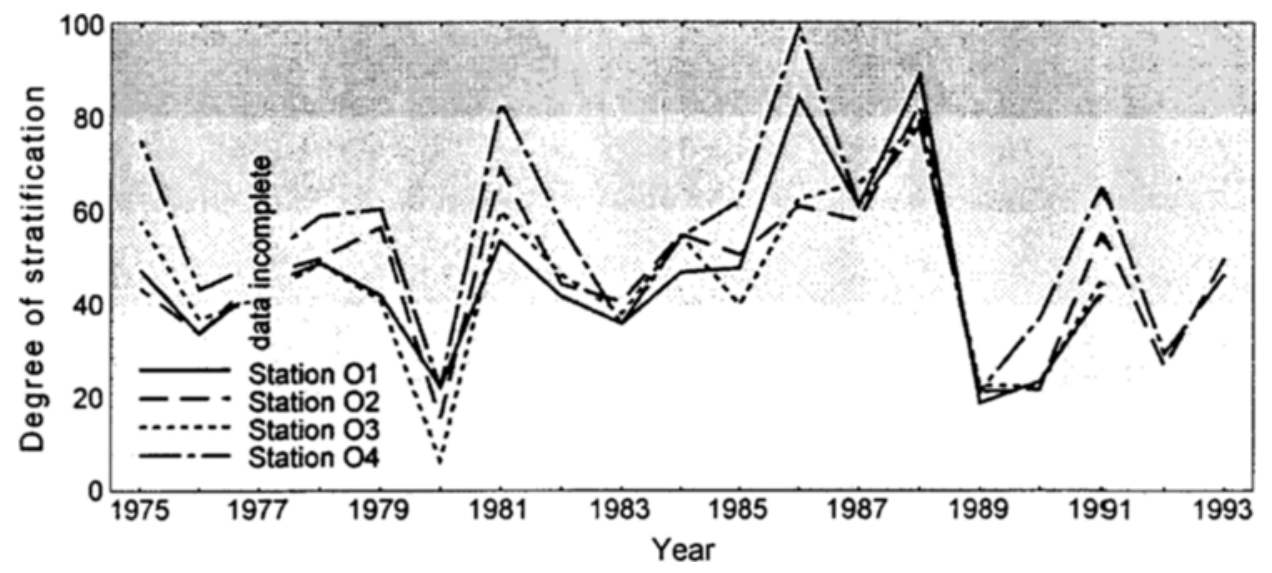

Fig. 10. Degree of vertical water stratification at Stations O1-O4 in 1975-93 (in percent of maximum stratification measured at Station $\mathrm{O} 2$ in 1988 )

\section{DISCUSSION}

Macrobenthos surveys carried out before 1980 by Lenz (1878), Anonymous (1901-05, cited in Stein et al., 1990), Hagmeier (1930) and Schulz (1969) showed that the zones in Lübeck Bay below $20 \mathrm{~m}$ depth are greatly impoverished when compared with the more shallow or open zones of Mecklenburg Bay. However, large populations of Capitella capitata and Polydora ciliata colonized in those deeper zones in the early $1980 \mathrm{~s}$, followed by predacious species such as Halicryptus spinulosus, Bylgides sarsi and Anaitides maculata (Gosselck \& Georgi, 1984). The benthos collapsed again in late summer when oxygen conditions were poor (Gosselck et al., 1987). The data presented in this paper suggest that there was, as a rule, benthic recovery in the spring and summer, with an increase in biomass and faunal diversity, and a decline toward the autumn. Both recruitment and decline of the benthos varied greatly from year to year. For example, large populations of C. capitata and $P$. ciliata similar to those observed in the early 1980s colonized at Stations LB7 and LB12 only in 1988. Also, the benthos changed differently at several locations, in the inner and outer zones, and at the northern and southern shore. Episodes of benthic recolonization occurred at Stations LB7 and LB12, near the southern shore, particularly in 1980-83, 1988 and 1990. The benthos changed little between these events, with the same impoverished community re-establishing itself when oxygen conditions deteriorated. Changes in the benthos were more regular at Stations MB5 and MB6, near the northern shore of Lübeck Bay. Neither the colonization episode observed at Stations LB7 and LB12 in the spring 1988 nor the strong oxygen depletion in southern Mecklenburg Bay in August 1988 (Prena, 1994) showed up near the north shore. Thus, our more recent observations on the spatial and temporal changes in the benthos distribution in Lübeck Bay represent some aspects not evident from earlier studies: (1) the temporal changes in the benthic community were locally distinct, with rather episodic recolonization events near the south shore and more periodic changes near the north shore; (2) mass occurrence of the opportunistic polychaetes $C$. capitata and P. ciliata was irregular and not obviously connected with re-oxygenation of the deep water; (3) some species belon- 


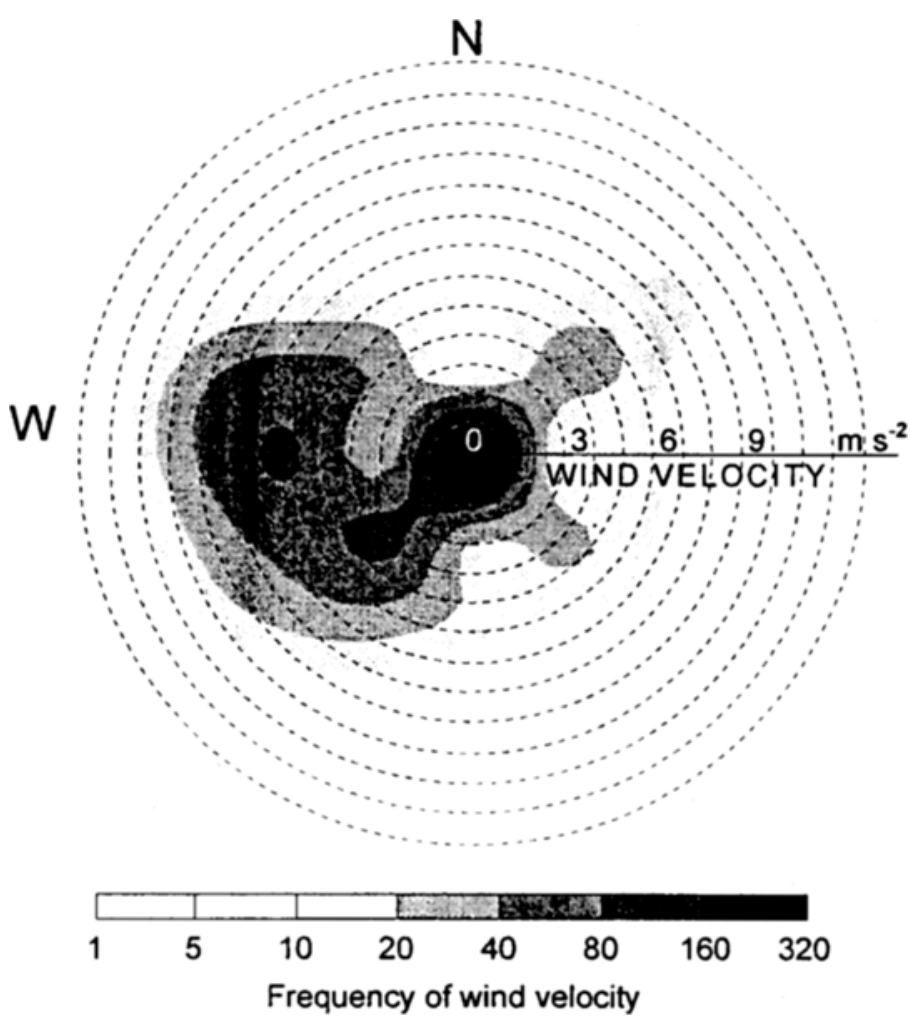

Fig. 11. Frequency of wind velocity and direction during the period July/September measured at Boltenhagen weather station in $1980-91$, based on 3 -h means

ging to the Syndosmya alba-community (Petersen, 1913; Thorson, 1957) colonized occasionally in the deep zones of Lübeck Bay. These observations will be discussed in the following text.

A strong pycnocline was established in Lübeck Bay as a rule in July-September causing low-oxygen situations. Somewhat better oxygen conditions prevailed in the more open zones of Mecklenburg Bay where stratification was weaker. These observations are in agreement with those described by Matthäus $(1984,1992)$. The influence of special wind conditions in the breaking up of the stratification of the water masses was investigated by Dietrich \& Weidemann (1952). They showed that west wind may transport surface water toward Mecklenburg Bay while deep water wells up in inner Lübeck Bay. Near-bottom currents remained weak even during periods of strong west wind. Winds from the east caused advection of surface water into Lübeck Bay replacing the deep water at the northern shore. At the same time, an outflow occurred along the southern shore 


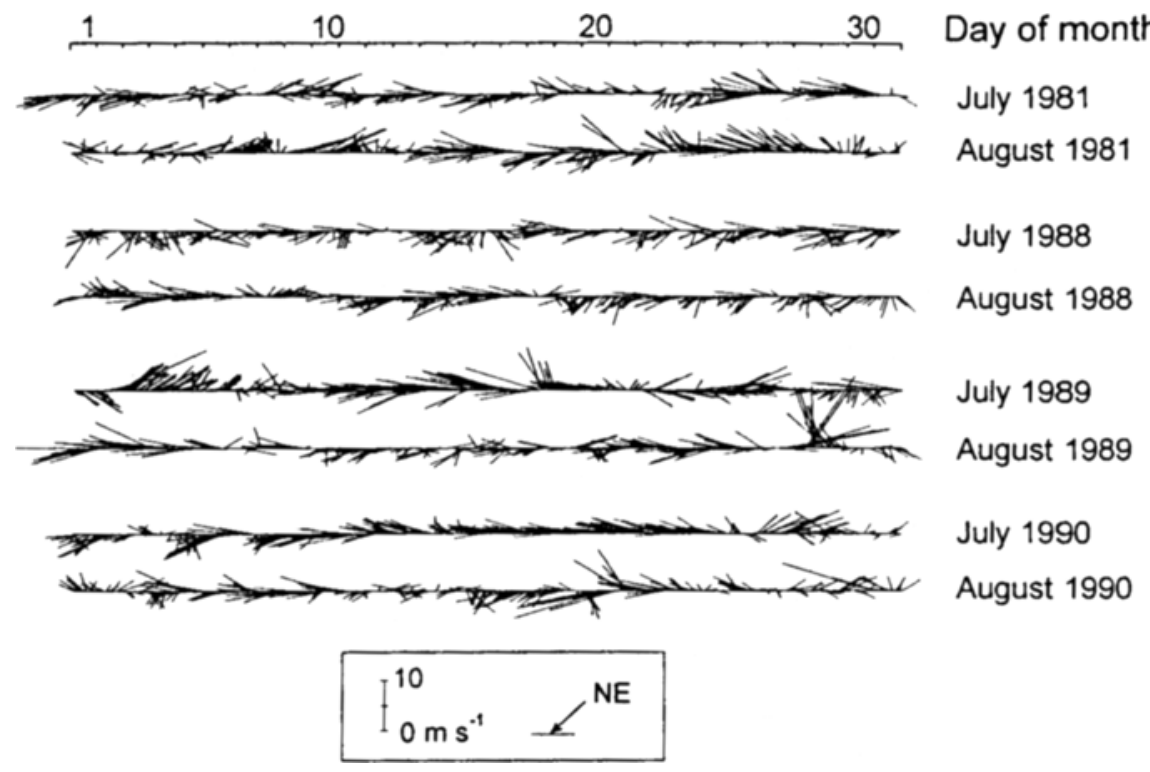

Fig. 12. 3-h means of wind velocity and direction at Boltenhagen weather station during the July/ August period of some years with strong $(1981,1988)$ and weak $(1989-90)$ water stratification. Situations with prevailing east wind component are shaded

to Mecklenburg Bay. Dietrich \& Weidemann (1952) found also evidence that winds from the east caused maximum water current speed above the sea floor and replacement of the deep water in Lübeck Bay. These observations on the influence of wind on current distribution were confirmed by Schulz (1968) and by some routine measurements presented by Lange (1987). Lange (1987) suggested that, besides the winds, water exchange processes in the Belt Sea affected the current along the shore of Lübeck Bay. Data collected at Boltenhagen weather station in 1980-91 showed that west winds prevailed during the period of maximum water stratification in Lübeck Bay. This may cause deep-water intrusions from Mecklenburg Bay, with probably little improvement in the oxygen condition of the deep water in Lübeck Bay. However, oxygen-poor deep water wells up in the inner reaches of the Bay offering a plausible explanation for the impoverished benthos found in some shallow areas, such as Stations MB7 and MB8. On the other hand, east wind may improve the oxygen conditions along the north shore by replacing the deep water, while more southern areas are only affected by longer lasting wind events (Dietrich \& Weidemann, 1952). Moreover, east winds of shorter duration may cause outflow of oxygen-poor deep water along the southern shore impacting the benthos there. This would explain why Stations LB7 and LB12 show only episodic benthic recruitment while recolonization at the north shore exhibits greater regularity.

Mass occurrence of the opportunistic polychaete species Capitella capitata and Polydora ciliata is usually interpreted as an indication of nutrient enrichment (Pearson \& Rosenberg, 1978). However, the irregularity in the occurrence of such events led to the conclusion that re-oxygenation of the deep water may exert greater influence in Lübeck 


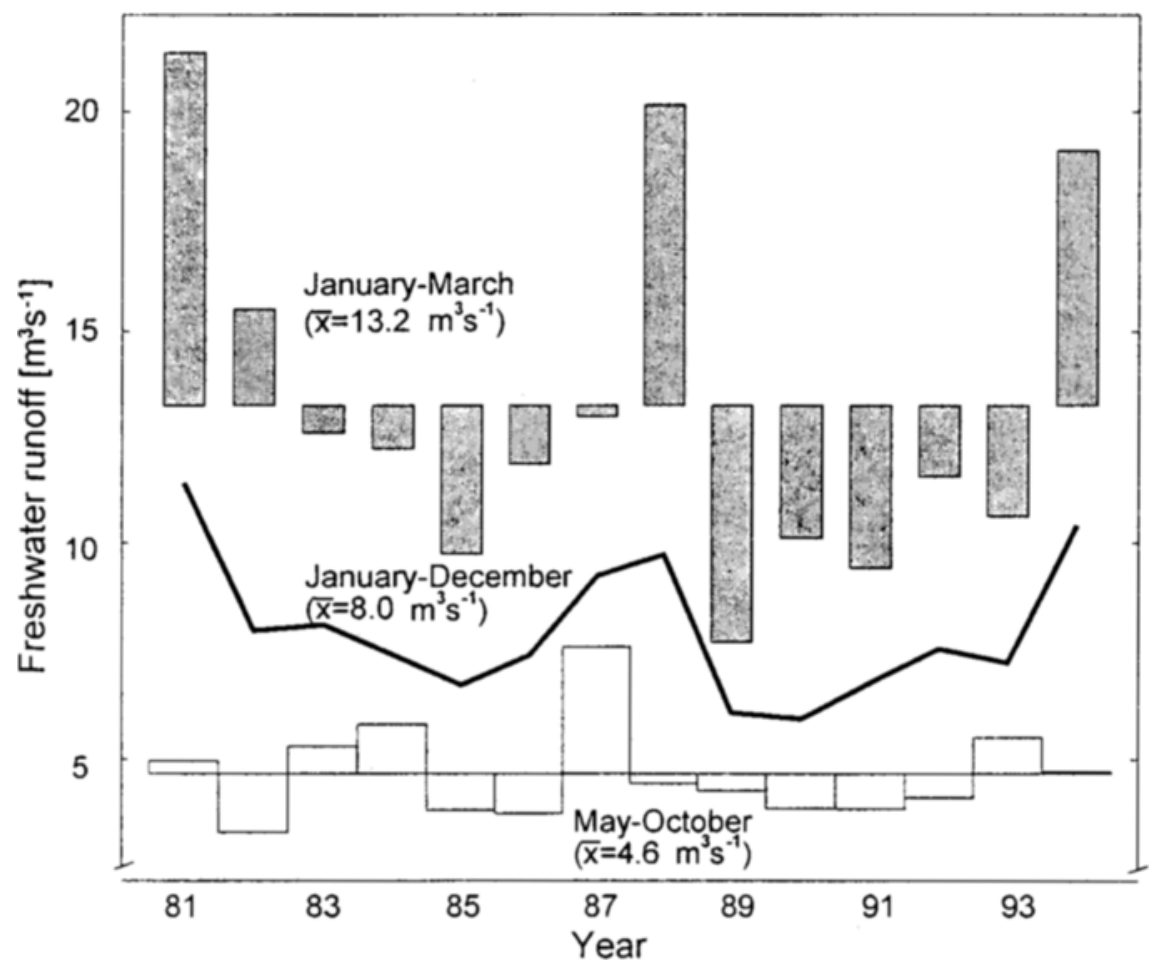

Fig. 13. Anomaly in the fresh water runoff of Trave river at Sehmsdorf in 1981-94 for the time periods January-March, May-October and January-December

Bay (Gosselck et al., 1987). Episodes of benthic recolonization were apparent along the south shore of Lübeck Bay in 1980-84, 1988 and 1990-91. Large populations of C. capitata and $P$. ciliata occurred in the first two of these episodes. Benthic recolonization was different in the summer 1990 when a diverse fauna colonized and C. Capitata was as a rule absent. The data suggest that the spring increase of $C$. capitata observed in 1981 and 1988 was possibly related to riverine nutrient discharge rather than to re-oxygenation of the deep water. The local confinement of the 1981 mass occurrence of $C$. capitata and $P$. ciliata to the eutrophic inner zones of Lübeck Bay (Gosselck \& Georgi, 1984) may be another indicator of the significance of nutrients on the recruitment of these species. On the other hand, the benthos was notably diverse at Stations LB7 and LB12 in the summer 1990 when water stratification was exceptionally weak. Also, large populations of Diastylis rathkei occurred at Stations MB5 and MB6 in other summers with below average water stratification, such as 1980 and 1990-93. It appears plausible that opportunistic species, particularly $C$. capitata, colonized when large amounts of nutrients were discharged by freshwater runoff and the benthos was previously impoverished. Immigration of some other species was more successful when water stratification was weak and better oxygen conditions prevailed.

Exceptionally large numbers of Syndosmya alba, Corbula gibba and Mysella bidentata were found at Stations LB7 and LB12 in 1990, a year with weak vertical water stra- 
tification. The populations of these species also increased at the shallow Station MB10 in 1989-93, suggesting a previous episode of larval immigration from the Kattegat. The episodic occurrence of these and some other species was illustrated for Kiel Bay by Rumohr (1990) and Weigelt (1991), by means of a 21-year data series. There is considerable agreement in the temporal occurrence of those species in Kiel Bay (Rumohr, 1990; Weigelt, 1991), Lübeck Bay (this study), and southern Mecklenburg Bay (Gosselck, unpubl.). However, immigration was less intensive in the shallow areas east of Lübeck Bay compared to those in Kiel Bay and south of Fehmarn Island. The spatial distribution of the benthos presented by Schulz (1969) shows that several of these species have an isolated occurrence in southern Mecklenburg Bay. These populations depend greatly on larval immigration from waters with greater salinity (Thorson, 1957). Oceanographic conditions which favour these immigrations appear to occur irregularly, thus creating the observed interannual differences in the species community. Furthermore, larval colonization is likely to be confined to the zones with better oxygen conditions, i.e. the outer and shallow zones of Lübeck Bay. Recolonization in zones with longer-lasting oxygen deficiency may occur later through post-larval dispersal from refuge areas.

In 1988, a major oxygen depletion occurred in some shallow areas of southern Mecklenburg Bay (Prena, 1994). Deleterious impact on the benthos attributable to this event was not apparent in the data presented here. This indicates that the anoxic deep water which had caused that impact advected from central Mecklenburg Bay rather than Lübeck Bay. However, there was some increase in the number of species present at Station MB8 prior and posterior to the 1988 oxygen depletion. A similar increase was assessed in a shallow zone of Wismar Bay in March 1989 (Prena, 1994). Lack of oxygen may have forced the benthos to withdraw temporarily to the more shallow zones.

In summary, we found indications that oceanographic conditions create locally distinct temporal changes of the zoobenthos in the 16-21 m deep zones of southwest Mecklenburg Bay. Riverine nutrient discharge in winter and water stratification in summer affecting larval immigration and colonization were related to some notable deviations from average observations in the benthos. This result calls for a better understanding of the influence of weather on oceanography and benthos of the study area. Sound a priori knowledge about the causal connection between benthos distribution and local significance of key environmental variables should support future environmental assessments in this variable environment.

Acknowledgements. We wish to thank N. Schmitz (Rostock University) for technical assistance. T. Schmidt (IO Warnemünde), E. Brandt (LW Kiel), M. v. Weber and S. Klitzsch (both LAUN Stralsund) provided additional data. T. Schmidt gave oceanographic advice. S. Schulz (Rostock), M. Powilleit (IO Warnemünde) and K. Macisaac (Dartmouth) commented on the draft. We are particularly obliged to B.v. Bodungen (IO Warnemünde) for his helpful attitude in providing hospitality and working facilities for the first author.

\section{LITERATURE CITED}

Dietrich, G. \& Weidemann, H., 1952. Strömungsverhältnisse in der Lübecker Bucht. - Küste 1,69-89.

Ehrhardt, M. \& Wenck, A., 1984. Wind pattern and hydrogen sulphide in shallow waters of the Western Baltic Sea, a cause and effect relationship? - Meeresforschung 30, 101-110.

Gosselck, F., 1992. Zwischen Artenreichtum und Tod - Die Tiere des Meeresbodens der Lübecker 
Bucht als Maßstab ihrer Umwelt. - Ber. Ver. Natur und Heimat naturhist. Mus. Lübeck 23/24, 41-60.

Gosselck, F. \& Georgi, F., 1984. Benthic recolonization of the Lübeck Bight (Western Baltic) in 1980/81. - Limnologica 15,407-414.

Gosselck, F., Doerschel, F. \& Doerschel, T., 1987. Further developments of macrozoobenthos in Lübeck Bay, following recolonisation in 1980/81. - Int. Revue ges. Hydrobiol. 72, 631-638.

Hagmeier, A., 1930. Die Bodenfauna der Ostsee im April 1929 nebst einigen Vergleichen mit April 1925 und Juli 1926. - Ber. dt. wiss. Kommn Meeresforsch. 5, 78-95.

Lange, W, 1987. Statistical results of current measurements in the western Baltic Sea. In: Proceedings 15th Conference of Baltic Oceanographers, Copenhagen 1986. Charlottenlund, Mar. Pollut. Lab. 1, 316-335.

Lenz, H., 1878. Die wirbellosen Thiere der Travemünder Bucht. Theil 1. - Jber. Kommn. wiss. Unters. dt. Meere Kiel. 5 (Anh.), 1-24

Matthäus, W., 1984. Zur mittleren jahreszeitlichen Veränderlichkeit von Temperatur und Salzgehalt in der Mecklenburger Bucht. - Beitr. Meereskde, 50, 9-23.

Matthäus, W., 1992. Zur Ozeanographie der Lübecker Bucht. - Ber. Ver. Natur und Heimat naturhist. Mus. Lübeck 23/24, 19-33.

Olsgard, F. \& Gray, J. S., 1995. A comprehensive analysis of the effects of offshore oil and gas exploration and production on the benthic communities of the Norwegian continental shelf. - Mar. Ecol. Prog. Ser. 122, 277-306.

Pearson, T. H. \& Rosenberg, R., 1978. Macrobenthic succession in relation to organic enrichment and pollution of the marine environment. - Oceanogr. mar. Biol. 16, 229-311.

Petersen, C. G. J., 1913. Valuation of the sea. II. The animal communities of the sea bottom and their importance for marine zoogeography. - Rep. Dan. biol. Stn 21, 1-44.

Prena, J., 1994. Oxysen depletion in Wismar Bay (Western Baltic Sea) 1988. - Arch. Fish. Mar. Res. 42,77-87.

Rumohr, H., 1990. Kiel Bay. - Baltic Sea Environ. Proc. 35B, 226-232.

Schulz, S, 1968. Rückgang des Benthos in der Lübecker Bucht. - Monatsber. dt. Akad. Wiss. Berlin 10, 748-754.

Schulz, S., 1969. Benthos und Sediment in der Mecklenburger Bucht. - Beitr. Meereskde 26, 21-46.

Stein, U., Hukriede, W. \& Rumohr, H., 1990. Historische Benthosdaten aus Nord- und Ostsee in den Jahren 1902-1912. - Mitt. zool. Mus. Univ. Kiel (Suppl.) 3, 1-189.

Thorson, G., 1957. Bottom communities. In: Treatise of marine ecology and palaeoecology. Ed. by J. W. Hedgpeth. Geol. Soc. Am., New York, 1, 461-534. (Mem. geol. Soc. America 67.)

Weigelt, M., 1991. Short-and long-term changes in the benthic community of the deeper parts of Kiel Bay (Western Baltic) due to oxygen depletion and eutrophication. - Meeresforschung 33, 197-224. 